\title{
Several Different Versions of the Same Russian Poem
}

A much-translated early poem by Anna Akhmatova:

Все мы бражники здесь, бкуАницы,

Как невесемо вместе нам!

На стенах цветы и птицы

Томятся по облакам.

Ты куришь черную трубку,

Так странен дымок над ней.

Я надема узкую юбку

Чтоб казаться еще стройней.

Навсегда забиты окошки:

Что там, изморозь или гроза?

На глаза осторожной кошки

Похожи твои глаза.

$\mathrm{O}$, как сердце мое тоскует!

Не смертного Аь часа жАу?

А та, что сейчас танцует

Непременно будет в аду.

1 января 1913 г. 
Translations:

We are all carousers and loose women here;

How unhappy we are together!

The flowers and birds on the wall

Yearn for the clouds.

You are smoking a black pipe,

The puff of smoke has a funny shape.

I've put on my tight skirt

To make myself look still more svelte.

The windows are boarded up forever.

What's out there-hoarfrost or a storm?

Your eyes resemble

The eyes of a cautious cat.

Oh, I am sick at heart!

Isn't it the hour of death I await?

But that woman dancing now

Will be in hell, no doubt.

January 1, 1913

Judith Hemschemeyer, The Complete Poems of Anna Akhmatova: Expanded Edition, ed. Roberta Reeder (Boston: Zephyr Press, 1992), 135-136. 
We are heavy-drinkers and whores, What a joyless, miserable crowd! There are flowers and birds on the walls And the birds all grieve for a cloud.

You are smoking your old black pipe, And the smoke looks strange over it. The skirt that I'm wearing feels tight, But I hope that it makes me look fit.

What's the weather-thunder or ice?

Here, the windows are all boarded shut.

I examine your face and your eyes

Have the look of a sly cautious cat.

Ah, what sadness I'm feeling inside!

Am I waiting for death's solemn bell?

And that girl, who's been dancing all night,-

She will surely end up in hell.

January 1, 1913

Andrey Kneller, Final Meeting (Boston: Kneller, 2008), 31. 
"We're All Drunkards Here..."

We're all drunkards here, and harlots:

how wretched we are together!

On the walls, flowers and birds

wait for the clouds to gather.

You puff on your burnished pipe,

strange shapes above you swim,

I have put on a narrow skirt

to show my lines are trim.

The windows are tightly sealed.

What brews? Thunder or sleet?

How well I know your look,

your eyes like a cautious cat.

O heavy heart, how long

before the tolling bell?

But that one dancing there

will surely rot in hell!

- 1 January 1913

Stanley Kunitz and Max Hayward, Poems of Akhmatova (Boston and New York: Houghton Mifflin Company, 1973), 51. 
We're harlots here and carousers,

How unhappy are we all!

On the walls the birds and flowers

Are homesick for the clouds.

The black pipe you are holding-

So strange the puffs of smoke.

To appear even more slender

I put on my narrow skirt.

Blocked forever are the windows.

Is there frost or a storm outside?

But the eyes of a wary house cat

Are not unlike your eyes.

Oh, how my heart is aching!

Do I wait for the hour of death?

But the woman who now dances

Will surely be in hell.

January 1, 1913

Frances Laird, Swan Songs: Akhmatova and Gumilev (C) Frances Laird, 2002), 218-219. 
All of us here are hookers and hustlers.

We drink too much, and don't care.

The walls are covered with birds and flowers

that have never seen sunshine or air.

You smoke too much. There's always a cloud

of nicotine over your head.

Do you like this skirt? I wore it on purpose.

I wanted to show lots of leg.

The windows here have been covered forever.

Is it snowing out? ... maybe it's rain.

You've got that look in your eyes again,

like a cat in a crouch for a kill.

Sometimes I feel this awful pain,

as if someone were breaking a spell.

Take a good look at that one over there!

She's dancing her way into hell!

January 1, 1913

Paul Schmidt, The Stray Dog Cabaret: A Book of Russian Poems, eds. Catherine

Ciepiela and Honor Moore (New York: NYRB Classics, 2006), 6.

(This poem is included in the section of works by Akhmatova, below.) 
We're all drunkards here. Harlots.

Joylessly we're stuck together.

On the wall, scarlet

Flowers, birds of a feather,

Pine for clouds. Your black pipe

Makes strange shapes rise.

I wear my skirt tight

To my slim thighs.

Windows tightly shut.

What's that? Frost? Thunder?

Did you steal your eyes, I wonder,

From a cautious cat?

O my heart, how you yearn

For your dying hour...

And that woman dancing there

Will eternally burn.

D. M. Thomas, Anna Akhmatova: Selected Poems (London: Penguin Books, 1985), 22-23. 
For more information about the history of Russian poetry, we suggest these books, some of which are mentioned elsewhere in this volume:

Obolensky, Dimitri, ed. The Heritage of Russian Verse (formerly The Penguin Book of Russian Verse), with plain prose translations. Bloomington and Indianapolis: Indiana University Press, 1976.

Scherr, Barry. Russian Poetry: Meter, Rhythm and Rhyme. Berkeley: University of California Press, 1986.

Wachtel, Michael. The Cambridge Introduction to Russian Poetry. Cambridge, UK and New York: Cambridge University Press, 2004. 